\title{
An Investigation into Stylistic Devices in Emily Dickinson's and Sylvia Plath's Poetry
}

\author{
Romana Jabeen Bukhari ${ }^{1} \&$ Tahira Asgher ${ }^{1}$ \\ ${ }^{1}$ Department of English, The Government Sadiq College Women University Bahawalpur \\ Correspondence: Tahira Asgher, Department of English, The Government Sadiq College Women University \\ Bahawalpur, Pakistan. E-mail: abeehamalika@gmail.com
}

Received: February 28, 2017 Accepted: May 22, 2017 Online Published: July 15, 2017

doi:10.5539/ijel.v7n4p207 URL: http://doi.org/10.5539/ijel.v7n4p207

\begin{abstract}
This paper focuses on the use of stylistic devices in Emily Dickinson's and Sylvia Plath's poetry. It differentiates between the phonological stylistic devices as alliteration, consonance and semantic stylistic devices as simile and personification. The study is carried out on five randomly selected poems from each poetess using the mixed modal research with the tool of tabulation to quantify the findings. Qualitative approach is used for analysis. The analysis provides a clear picture of the use of stylistic devices in Emily Dickinson and Sylvia Plath's poetry.
\end{abstract}

Keywords: stylistics, stylistic devices, classification, phonological, semantics, alliteration, consonance, simile, personification, mixed research

\section{Introduction}

Literature is a multidimensional phenomenon. The complex and complicated nature of literature has given birth to divergent and varied approaches about literature. Similarly there are certain varied conventional and unconventional ways and approaches to interpret a piece of literature. We can say that literature is the expression of life through the medium of language. Language is an essential material source in literature because any piece of literature is a work of language first e.g., poetry. Literature is the reflection of society. It allows us to enjoy, observe and learn the style and languages of people from past centuries, verses of the poems shows really sincere emotions and arouse sentiments among readers and helps them to learn the realities of life enlighten their minds and broaden the vision of readers.

The very process of composing literature invokes a desire among the readers to be more appreciative of the true spirit and real meanings of that piece of literature that they read. But the job is not easy since the readers are supposed to be aware of literary conventions and historical background of any piece of literature. But they must possess the sensibility of language in which it is written and the grammatical and stylistic technicalities involved in its composition.

In the past centuries a movement was initiated that has gained momentum especially in the modern days that stresses the claim that one can get real meanings of the text by analyzing critically its stylistic and linguistic technicalities. This effort or this movement is called stylistics.

There have been a lot of studies so far, on stylistics and the investigation of stylistic devices in literature. Plenty of the books and articles about this study have been published especially in the past few decades respectively presenting insightful notions and methodologies.

Regarding the importance of stylistic devices in poetry I intended to carry out a comparative study of investigation of stylistic devices in Emily Dickinson and Sylvia Plath poetry, in order to obtain more insight and to draw out a comparison in stylistic devices used in Dickinson and Plath's poetry.

\section{Literature Review}

According to Leech (1969) style is the mode in which something is spoken, written or performed. Leech \& Short (1981, p. 10) consider that the word "style" has a fairly uncontradictory meaning: it refers to the manner in which language is used in a given framework, by a given person, for a given reason, and so on. Birch (1989, p. 10) says that language and style never moves away from a meditation on the preeminence of words; he believes resolutely that these words somehow "contain" meanings and is efficiently language manipulated in ways that 
signal it as diverse from "ordinary" language.

Such avowedly introducing books as Turner (1973), Chapman \& Clark (2014), Cluysenaar (1976), Wright \& Hope (1996) are considered as the first detailed dictionaries of stylistics presenting stylistic theories and are one of the major contributors to the development of this field of study. But the drawback of these works is that these dealt only with some specific aspects and dimensions of stylistics and do not narrate much about the whole context of this discipline.

From 1950 onwards stylistics began to realize the need to ascertain their field up till the emergence of practical and pedagogical stylistics in 80s. Hough (1969) gives the first historical review of stylistics including all the major stylistics and critics as Bally, Spitzer, Holloway, and Richard Barthes.

So stylistics can be defined as an analytical science which covers all the expressive aspects of language i.e., phonology, morphology, syntax and lexicology.

\subsection{Stylistic Devices}

Many of the researchers have tried to find out stylistic devices in English poetry as well as in poetry of other languages also. Though there have been a lot of investigation on Emily Dickinson and Sylvia Plath's poetic style individually but the aim of this study is to investigate some of the stylistic devices that fall into the category of semantic and phonological stylistic devices and make a comparative study of the use of stylistic devices in both American poetesses which is a new attempt on my part.

Cuddon (2013), Katie Wales (2014), Leech Geoffrey (1969) had worked a lot on stylistic devices and presented their sound, authentic and comprehensible dictionaries on stylistic devices.

Phonological stylistic devices that will be the focus of this study are:

\subsubsection{Consonance}

Consonance refers to the reoccurring of indistinguishable or similar consonant sounds before and after different vowels. Cuddon defines it: "The close repetition of identical consonant sounds before and after different vowels. For example: slip-slop; creak-croak; black-block" (p. 153).

\subsubsection{Alliteration}

Alliteration is one of the phonological stylistic devices. It is the repetition of same sound either consonant or vowel in a verse or a sentence. It can be immediate or non-immediate. These are the sounds especially repeated at the beginning of the words or stressed syllables. According to Cuddon: "A figure of speech in which consonants, especially at the beginning of words or stressed syllables, are repeated. It is a very old device indeed in English verse (older than rhyme) and is common in verse generally. It is used occasionally in prose" (p. 22).

And in semantic stylistic devices the focus of the study will be following.

\subsection{Personification}

Personification is a device that means impersonation or embodiment of some quality or abstraction. According to Cuddon, "The impersonation or embodiment of some quality or abstraction; the attribution of human qualities to inanimate objects" (p. 529). In other words giving attributes of humans or human qualities to some inanimate being or objects is called personification.

\subsubsection{Simile}

Simile is one of the stylistic devices that is used to make comparison between two things. It came under the category of semantic stylistic devices as it affects the meaning of verse and somehow enhances it. It is a direct comparison between two or more than two entities. According to Cuddon, "A figure of speech in which one thing is likened to another, in such a way as to clarify and enhance an image. It is an explicit comparison (as opposed to the metaphor, q.v., where the comparison is implicit) recognizable by the use of the words "like" or "as". It is equally common in prose and verse and is a figurative device of great antiquity" (657).

\section{Methodology of the Study}

In this study a random sample of five poems from Emily Dickinson and Sylvia Plath each will be quantitatively analyzed in terms of phonology and semantics devices. After that the data will be analyzed qualitatively with the tool of tabulation in order to assess the quantity of stylistic devices used in Emily and Sylvia's poetry and to conduct a comparative study or to compare the poetry of both writers. Guba \& Lincoln (1994) noted that "Both qualitative and quantitative methods may be used appropriately with any research paradigm" (p. 105). Similarly, Guba \& Lincoln (2005) reiterated that "within each paradigm, mixed methodologies (strategies) may make 
perfectly good sense" (p. 200)

\subsection{Technique for Analysis of Data Analysis}

Tabulation for the analysis of data and for findings.

To conduct this study I have selected five well-known poems of Emily Dickinson and Sylvia Plath each. All these collected poems have been composed in nineteenth and twentieth century.

\section{Data Analysis}

\subsection{Poetic Analysis of Emily Dickenson}

There is a Certain Slant of Light Phonological stylistic devices: Alliteration, Consonance

\begin{tabular}{lll}
\hline There is a certain slant of light & Alliteration & Consonance \\
\hline & + & + \\
Quantity & 3 & 3 \\
\hline
\end{tabular}

Interpretation:

In this poem alliteration is used 3 times and consonance also 3 times.

Examples of alliteration:

1). There is a certain slant of light

2). That oppresses like the weight.

3). Heavenly hurt it gives us.

Examples of Consonance:

1). Winter afternoons.

Of cathedral tunes.

2). We can find no scar.

Where the meanings are.

3). Shadows hold their breath

On the look of death

\section{Semantic Stylistic Devices: Simile, Personification.}

\begin{tabular}{lll}
\hline There is a certain slant of light & Simile & Personification \\
\hline & + & + \\
Quantity & 1 & 3 \\
\hline
\end{tabular}

\section{Interpretation:}

In this poem 1 time simile and 3 times personification is used.

\section{Examples of Simile:}

1) That oppresses like the weight.

\section{Examples of personification:}

1) There is a certain slant of light that oppresses.

2) When it comes the landscape listens.

3) Shadows hold their breath. 
Safe in Their Alabaster Chambers

Phonological Stylistic Devices: Alliteration, Consonance

\begin{tabular}{lll}
\hline Safe in their Alabaster Chambers & Alliteration & Consonance \\
\hline & + & + \\
Quantity & 5 & 2 \\
\hline
\end{tabular}

\section{Interpretation:}

In this poem 5 times alliteration and 2 times consonance is used.

\section{Examples of Alliteration:}

1) Sleep the meek members of resurrection.

2) Light laughs the breeze.

3) Babbles the bee in Solid ear.

4) Diadems drop and Doges Surrender.

5) Soundless as Dots and disk of Snow.

\section{Examples of Consonance:}

1) Sleep the meek members of resurrection

Rafter of Satin

2). Untouched by morning and untouched by noon

Rafter of Satin, and roof of stone

\section{Semantic Stylistic Devices: Simile, Personification}

\begin{tabular}{lll}
\hline Safe in their Alabaster Chambers & Simile & Personification \\
\hline & + & + \\
Quantity & 1 & 6 \\
\hline
\end{tabular}

\section{Interpretation:}

In this poem 1 time simile and 6 times personification is used.

\section{Examples of simile:}

1) Soundless as dots on disk of snow

\section{Examples of personification:}

1) Light laughs the breeze in her castle above them.

2) Babbles the bee in the solid ear.

3) Pipe the sweet bird in ignorant cadence.

4) Worlds scoop their arcs

5) and firmaments row

6) dogs surrender

\section{A Bird Came Down the Walk}

Phonological Stylistic Devices: Alliteration and Consonance

\begin{tabular}{lll}
\hline A bird Came down the Walk & Alliteration & Consonance \\
\hline & + & + \\
Quantity & 6 & 2 \\
\hline
\end{tabular}

\section{Interpretation:}

In this poem 6 times alliteration and 2 times consonance is used. 


\section{Examples of alliteration:}

1) He stirred his velvet head.

2) Than Oars divide the Ocean.

3) And he unrolled his feathers

4) And rode him softer Home

5) Too silver for seam

6) Or butterflies, off Banks of noon.

Examples of Consonance:

1) From the convenient grass

Let the beetle pass

2). Too silver for a seam

Leap, plashless as they swim

Semantic Stylistic Devices: Simile, Personification

\begin{tabular}{lll}
\hline A bird Came down the Walk & Simile & Personification: \\
\hline \multirow{3}{*}{ Quantity } & + & + \\
& 2 & 3 \\
\hline
\end{tabular}

\section{Interpretation:}

In this poem 2 similes and 3 times personification is used.

\section{Examples of simile:}

1) They look like frightened beads.

2) Like one in danger cautious.

Example of personification:

1) They look like frightened beads.

2) rapid eyes that hurried all abroad

3) than oars divide the ocean

\section{The Soul Selects Her own Society}

Phonological stylistic devices: Alliteration and consonance.

\begin{tabular}{lll}
\hline This is my letter to the world & Alliteration & Consonance \\
\hline & + & + \\
Quantity & 3 & 4 \\
\hline
\end{tabular}

\section{Interpretation:}

In this poem 3 times alliteration and 4 times consonance is used.

\section{Examples of Alliteration:}

1) The soul selects her own society.

2) Then shut the door

3) Then close the valves of her attention.

\section{Examples of consonance:}

1) Then shut the door

Present no more

2) Unmoved she notes the chariots pausing 
3) Unmoved an emperor be kneeling

Upon her mat

4) I have known her from an ample nation

Then close the valves of her attention

Semantic Stylistic devices: simile, personification

\begin{tabular}{lll}
\hline The soul selects her own society & Simile & personification \\
\hline & + & + \\
Quantity & 1 & 4 \\
\hline
\end{tabular}

\section{Interpretation:}

In this poem 1 time simile and 4 times personification is used.

\section{Examples of simile:}

1) The valves of her attention like stone.

\section{Examples of personification:}

1) The soul selects her own society.

2) Then shuts the door

3) Unmoved - She notes the chariots - pausing.

4) I have known her from ample nation.

\section{The Wind Tapped like a Tired Man}

Phonological Stylistic Devices: Alliteration and Consonance

\begin{tabular}{lll}
\hline The wind tapped like a tired man & Alliteration & Consonance \\
\hline & + & + \\
Quantity & 2 & 3 \\
\hline
\end{tabular}

\section{Interpretation:}

1) In this poem 2 times alliteration and 3 times consonance is used.

\section{Examples of alliteration:}

No bone had he to bind him

2) His fingers if he passed.

\section{Examples of consonance:}

3) and like a host come in

My residence within

4) to offer whom a chair

a sofa to the air

5) his speech was like a push

from a superior bush

Semantic Stylistic devices: Simile and personification

\begin{tabular}{lll}
\hline The wind tapped like a tired man & Simile & personification \\
\hline & + & + \\
Quantity & 6 & 8 \\
\hline
\end{tabular}




\section{Interpretation:}

In this poem 6 times simile and 8 times personification is used.

\section{Examples of simile:}

1) The wind tapped like a tired man

2) and like a host come in

3) were as impossible as hand

4) his speech was like the push

5) let go a music as of tunes

6) Then like a timid man.

\section{Example of personification:}

1). The wind tapped like a tired man.

2). entered then my residence within

3). A rapid footless guest

4). No bone had he to bind him

5). His speech was like the push

6). His countenance, a billow

7). His fingers, if he pass, let go a music

8). He visited still flitting

Poetic analysis of Sylvia Plath

EIm

Phonological Stylistic Devices: Alliteration, Consonance

\begin{tabular}{lll}
\hline Elm & Alliteration & Consonance \\
\hline & + & + \\
Quantity & 5 & 1 \\
\hline
\end{tabular}

\section{Interpretation:}

In this poem Sylvia has used 5 times alliteration and 1 time consonance.

\section{Examples of alliteration:}

1) I know the bottom she says I know it.

2) Or the voices of nothing that was you madness.

3) Are those the faces of love, those pale irretrievable.

4) Echoing, echoing

5) That kill, that kill, that kill.

Example of consonance:

1) It is what you fear

I don't fear it. I have been there

Semantic stylistic devices: Simile, Personification.

\begin{tabular}{lll}
\hline EIm & Simile & Personification \\
\hline & + & + \\
Quantity & 3 & 6 \\
\hline
\end{tabular}




\section{Interpretation:}

In this poem from the semantic stylistic devices Sylvia has used 3 times simile and 6 times personification.

\section{Examples of simile:}

1). It's gone off like a horse.

2). This is a fruit tin white like arsenic.

3). That fly about like clubs.

\section{Examples of personification:}

1) The moon is so merciless she would drag me cruelly.

2) Or I shall bring you the sound of poison.

3) Listen, these are its hooves it has gone off

4) A wind of violence will tolerate no by standing.

5) I am inhabited by a cry. Nightly it flaps out. This dark thing that sleeps in me. All day, I feel its soft feathery turnings, its malignity.

\section{Lady Lazarus}

Phonological Stylistic Devices: Alliteration, Consonance

\begin{tabular}{lll}
\hline Lady Lazarus & Alliteration & Consonance \\
\hline & + & + \\
Quantity & 5 & 5 \\
\hline
\end{tabular}

\section{Interpretation:}

In this poem Sylvia has used 5 times alliteration and 5 times consonance.

\section{Examples of alliteration:}

1) My featureless face fine.

The nose the eye the full set of teeth.

2) Is an art like everything else?

3) To the same place the same face the same brute.

4) Soon soon the flesh.

Examples of consonance:

1) Gentlemen ladies

These are my hands and knees

2) Nevertheless I am the same identical women

First it happened I was ten

3) I do it exceptionally well

I do it so it feels like hell

4) I turn and burn

I underestimate your great concern.

5) The full set of teeth

The sour breath

Semantic stylistic devices: Simile, Personification.

\begin{tabular}{lll}
\hline Lady Lazarus & Simile & Personification \\
\hline & + & + \\
Quantity & 6 & 2 \\
\hline
\end{tabular}




\section{Interpretation:}

In this poem Sylvia has used 6 times simile and 2 times personification.

\section{Examples of simile:}

1) Bright as Nazi lampshade.

2) And like a cat I have nine times to die.

3) As a sea shell, they pick the worms off me.

4) Like sticky pearls.

5) Dying is an art like everything else.

6) I will eat the men like air.

\section{Examples of Personification:}

1). The big strips tease.

2). That same amused shout.

\section{The Bee Meeting}

Phonological Stylistic Devices: Alliteration, Consonance

\begin{tabular}{lll}
\hline The bee meeting & Alliteration & Consonance \\
\hline & + & - \\
Quantity & 4 & 2 \\
\hline
\end{tabular}

\section{Interpretation:}

There are 4 times alliteration and 2 times consonance in this poem.

\section{Examples of alliteration:}

1). Who are these people at the bridge to meet me? They are the villagers?

2). In my sleeveless summary dress.

3). Is she hiding is she eating honey she is very clever.

4). Whose is that long white box in the grove what have they accomplished, why I am so cold?

\section{Examples of consonance:}

1). In my sleeveless summary dress.

2). And they are all gloved and covered.

Semantic stylistics device: Simile, Personification

\begin{tabular}{lll}
\hline The bee meeting & Simile & Personification \\
\hline & + & + \\
Quantity & 4 & 6 \\
\hline
\end{tabular}

\section{Interpretation}

There are 4 times simile and 6 times personification in this poem.

\section{Examples of simile:}

1) I am nude as children neck.

2) Strips of tinfoil winking like people.

3) And leaves like bored hearts.

4) The white hive is snug as a virgin.

Examples of Personification:

1) Creamy bean flower with black eyes. 
2) The tendrils are dragging up that string.

3) Strips of tinfoil winking like people.

4) The white hive snug as a virgin, sealing off her brood cells, her honey, and quietly humming.

5) The barren body of hawthorn, etherizing its children.

6) The mind of the hive thinks this is the end of everything.

"You're"

Phonological Stylistic Devices: Alliteration, Consonance

\begin{tabular}{lll}
\hline You are & Alliteration & Consonance \\
\hline & + & + \\
Quantity & 4 & 3 \\
\hline
\end{tabular}

\section{Interpretation:}

In this poem, there are 4 times alliterations and 3 times consonance.

\section{Examples of alliteration:}

1) Clown like, happiest on your hands

2) Thumbs down on dodo's mode.

3) Mute as a turnip from the Fourth

Of July to All Fools' Day,

4) Bent backed Atlas.

\section{Example of consonance:}

1). A common sense thumbs down on the dodo's mode

2). Snug as a bud and at home

Like a sprat in a pickle jug.

3). A creel of eels, all ropples.

\section{Semantic stylistic devices: Simile, Personification.}

\begin{tabular}{lll}
\hline You are & Simile & Personification \\
\hline & + & + \\
Quantity & 14 & 1 \\
\hline
\end{tabular}

\section{Interpretation:}

In this poem 14 times simile and 1 time personification is used.

\section{Examples of Simile:}

1) Clown like happiest on your hand.

2) Gilled like a fish.

3) Wrapped up in you like a spool.

4) Trawling your dark as owls.

5) Jumpy as a Mexican bean.

6) Mute as turnip

7) Vague as fog

8) Looked for like a mail

9) bent backed Atlas

10) Snug as a bud 
11) Like a sprat in a pickle jar

12) A creel of eels, all ripples

13) Right like a well done sum

14) A clean slate with your own face on.

Examples of personification:

1) Bent backed Atlas

\section{Colossus}

Phonological stylistic: Alliteration, Consonance

\begin{tabular}{lll}
\hline Colossus & Alliteration & Consonance \\
\hline & + & + \\
Quantity & 5 & 2 \\
\hline
\end{tabular}

\section{Interpretation:}

In this poem 5 times alliteration and 2 times consonance is used.

\section{Examples of Alliteration:}

1) Pieced, glued and properly jointed.

2) Perhaps you consider yourself oracle

3) Scaling little ladders with glue pots and pails of Lysol

4) A blue sky out of Oresteia

5) Of your left ear, out of the wind.

\section{Examples of consonance:}

1) I shall never get you put together entirely

Pieced, glued and properly jointed

Mule bray pig-grunt and bawdy cackles

Proceed from your great lips

2) Counting the red stars and those of plum color

The sun rises under the pillar of your tongue

Semantic stylistic devices: simile, personification

\begin{tabular}{|c|c|c|}
\hline Colossus & Simile & Personification \\
\hline & + & + \\
\hline Quantity & 2 & 2 \\
\hline
\end{tabular}

\section{Interpretation:}

In this poem 2 times simile and 2 times personification is used.

\section{Examples of simile:}

1) I crawl like an ant in the morning.

1) You are pithy and historical as a Roman forum.

\section{Examples of personification:}

1) The sun rises under the pillar of your tongue.

2) My hours are married to a shadow

\section{Findings and Conclusions}

The focus of the study is to make a comparative study of the use of phonological devices as Alliteration and 
consonance and semantic stylistic devices as simile and personification in the poems of Emily Dickinson and Sylvia Plath. The purpose is to find the quantity of these stylistic devices used in their poetry and to make analysis in order to find out the similarities and difference in their use.

\section{Phonological devices in Emily Dickinson}

\begin{tabular}{lll}
\hline Number of poems & Stylistic devices & Quantity \\
\hline 5 & Alliteration & 19 \\
5 & Consonance & 14 \\
\hline
\end{tabular}

In the random sample of 5 poems of Emily Dickinson from the phonological stylistic devices 19 times alliteration and 14 times Consonance is used.

\section{Semantic stylistic devices in Emily Dickinson}

\begin{tabular}{lll}
\hline Number of poems & Stylistic devices & Quantity \\
\hline 5 & Simile & 11 \\
5 & Personification & 24 \\
\hline
\end{tabular}

In the random sample of 5 poems of Emily Dickinson from the semantic stylistic devices 11 times simile and 24 times personification is used.

\section{Phonological stylistic devices in Sylvia Plath}

\begin{tabular}{lll}
\hline Number of poems & Stylistic devices & Quantity \\
\hline 5 & Alliteration & 23 \\
5 & Consonance & 13 \\
\hline
\end{tabular}

In the random sample of 5 poems of Emily Dickinson from the phonological stylistic devices 23 times alliteration and 13 times consonance is used.

\section{Semantic stylistic devices in Sylvia Plath}

\begin{tabular}{lll}
\hline Number of poems & Stylistic devices & Quantity \\
\hline 5 & Simile & 29 \\
5 & Personification & 17 \\
\hline
\end{tabular}

In the random sample of 5 poems of Emily Dickinson from the semantic stylistic devices 29 times simile and 17 times personification is used.

From the findings above it is clearly evident that

1). Sylvia has used more alliteration as compared to Emily.

2). Emily has made more use of consonance as compared to Sylvia.

3). Sylvia has made use of more similes as compared to Emily.

4). Emily has used more personification as compared to Sylvia.

\section{References}

Birch, D. (1989). Language, literature and critical practice: Ways of analyzing text. London: Routledge.

Chapman, S., \& Clark, B. (2014). Pragmatic literary Stylistics. UK: Palgrave Macmillan. https://doi.org/10.1057/9781137023278

Cluysenaar, A. (1976). Introduction to literary stylistics: a discussion of dominant structures in verse and prose. London: B. T. Batsford Limited.

Cuddon, J. A. (2013). A dictionary of literary terms and literary theory. West Sussex: Wiley Blackwell.

Guba, E. G., \& Lincoln, Y. S. (2005). Paradigmatic controversies, contradictions, and emerging confluences. The 
Sage Handbook of Qualitative Research (3rd ed.) (pp. 191-215). Thousand Oaks, CA: Sage Publications Ltd.

Guba, E. G., \& Lincoln, Y. S. (1994). Competing paradigms in qualitative research. In N. K. Denzin \& Y. S. Lincoln (Eds.), The Sage Handbook of Qualitative Research (pp. 105-117). Thousand Oaks, CA: Sage.

Hough, G. (1969). Style and Stylistics. London: Routledge \& Kegan Paul.

Leech, G. N. (1969). A Linguistic guide to English poetry. London: Longman.

Leech, G. N., \& Short, M. (1981). Style in fiction: A linguistic introduction to English fictional prose. London: Longman.

Turner, G. W. (1973). Stylistics. Harmondsworth. Middlesex: Penguin Books.

Wales, K. (2014). A dictionary of stylistics. London: Routledge

Wright, L., \& Hope, J. (1996). Stylistics: A practical coursebook. London: Routledge.

\section{Copyrights}

Copyright for this article is retained by the author(s), with first publication rights granted to the journal.

This is an open-access article distributed under the terms and conditions of the Creative Commons Attribution license (http://creativecommons.org/licenses/by/4.0/). 